\title{
EDITORIAL: INTERDISCIPLINARIDADE
}

Verônica Maria de Araújo Pontes ${ }^{1}$

O tema interdisciplinaridade há muito tempo vem sendo discutido, questionado, exercitado e defendido. Propomos então uma discussão do seu conceito para que então possamos diferenciá-lo e propor mudanças a partir de pesquisas e relatos de experiência significativos para que sejam socializados e aprofundados.

Ao discutirmos esse tema voltamos à discussão anterior do que seja disciplinaridade, compartimentação do saber, especialização do conhecimento e as suas razões e finalidades.

O saber ao ser disciplinar se individualiza e potencializa a sua especialização, no entanto, ao separarmos saberes perdemos a noção do todo e o intercâmbio do conhecimento, o todo interligado se desfaz, as peças do complexo mundo e sua compreensão se desvinculam para criarem outros complexos solitários que criam outras necessidades particulares.

O conhecimento especializado permite um distanciamento do todo e dificulta a sua socialização e compreensão. Assim, falar em interdisciplinaridade hoje é quase uma necessidade real de compreendermos o mundo e sua complexidade e o nosso papel como seres humanos reais nesse mundo posto e diversificado.

A diversidade existente hoje deve ser compreendida a partir de princípios éticos, sociais, políticos, educativos que se entrelaçam aqui e agora e não no amanhã advindo de especialidades separativas e emergenciais.

Pensar com o olhar interdisciplinar envolve categorias explícitas da inclusão em que todos se conectam e vivenciam melhorias possibilitadoras de compreensão diversificada, que segundo Alvarenga et al. (2011) seria então um modo inovador na produção e apropriação do conhecimento que complementa e amplia a forma disciplinar.

Philippi Jr e Fernandes² (2015, p.59) afirmam: "ao princípio básico da disjunção, a interdisciplinaridade passa a propor a conjunção como proposta de (re)ligação dos saberes."

\footnotetext{
1 Pós-doutora em Literatura para a Infância pela Universidade do Minho (UMinho). Doutora em Educação pela Universidade de Campinas (Unicamp). Professora do Instituto Federal do Rio Grande do Norte (IFRN). Lattes: http://lattes.cnpq.br/5868116609416027. E-mail: veronicauern@gmail.com. 2 PHILIPPI JR, Arlindo; FERNANDES, Valdir. Práticas da Interdisciplinaridade no Ensino e pesquisa. Barueri: Manole, 2015.
}

R. Inf. Cult., Mossoró, v.1, n.2, p. 9-10, jul./dez. E-ISSN: 2674-6549. 
Entendemos que não estamos negando os saberes mas interligando-os para que assim possamos compreender o todo de forma mais ampla.

Morin ${ }^{3}(2003)$ explica que a interdisciplinaridade tanto pode significar diferentes disciplinas em torno de uma mesa ou troca e cooperação.

Fazenda ${ }^{4}$ (2008) garante que a interdisciplinaridade exige atitude de quem a faz e não pode ser aguardada como um fenômeno que acontece naturalmente mas que precisa que os seus atores a possibilitem efetivamente se concretizarem.

Para Philippi Jr e Fernandes ${ }^{5}$ (2015, p.63) o conceito de interdisciplinaridade "pressupõe uma nova forma de produção de conhecimento voltada aos fenômenos complexos". Busca-se assim agir entre as fronteiras que são disciplinares não apenas em trocas teóricas, metodológicas e tecnológicas mas com a criação de novas linguagens e instrumentais, religando conhecimentos, saberes que são originários do pensamento disciplinar.

Dessa forma, é que pensamos esse editorial enfocando a interdisciplinaridade como um pensamento, uma ação possível de ser realizada, não como um sonho mas como algo efetivamente real e acessível. Trazer em uma revista pesquisas que realcem a importância de se pensar unindo, interligando saberes é pensar em uma união entre saberes distantes, muitas vezes complexos mas possibilitadores de mudanças e reflexões em torno da melhoria educacional e sociocultural da humanidade, saindo assim da nossa zona de conforto para expor ao mundo uma forma de pensar e agir inclusiva e que não só acata a diversidade mas a torna possível de existir, de ser, de fazer-se compreendida e inclusa no processo de vida das pessoas.

A interdisciplinaridade proposta aqui pretende abordar diálogos variados entre pares que pesquisam, que ensinam, que fazem se tornar realidade o tema, que são capazes de compreenderem o tema abordado e serem defensores dele objetivando um saber/fazer/pensar diferente do que foi posto com a compartimentalização dos saberes.

Está posto então o desafio, agora abracemos-lhe e tornemos mediadores e socializadores de bons ensinamentos, boas práticas, bons pensamentos, enfim. Sucesso na empreitada complexa mas não impossível.

\footnotetext{
${ }^{3}$ MORIN, Edgar. A Cabeça Bem-feita: repensar a reforma, reformar o pensamento. 8.ed. Rio de Janeiro, Bertrand Brasil, 2003.

${ }^{4}$ FAZENDA, Ivani. O que é interdisciplinaridade? São Paulo: Cortez, 2008.

${ }^{5}$ PHILIPPI JR, Arlindo; FERNANDES, Valdir. Práticas da Interdisciplinaridade no Ensino e pesquisa. Barueri: Manole, 2015.
} 